\title{
Small and Medium Enterprises Business Strategy in Pandemic COVID-19
}

\author{
Darwis Harahap, Ferri Alfadri, Ayu Damayanti \\ Institut Agama Islam Negeri Padangsidimpuan \\ Jl. T. Rizal Nurdin, KM.4,5 Sihitang, Padangsidimpuan - Indonesia \\ E-mail: darwisharahap@iain-padangsidimpuan.ac.id
}

\begin{abstract}
,
The COVID-19 pandemic that has hit the world including Indonesia since early 2020 has had a significant impact on the Indonesian economy, especially in the Small and Medium Enterprises (SME's) sector. This study aims to determine an efficient business strategy to survive the COVID-19 pandemic in Padangsidimpuan City. This study uses descriptive qualitative analysis techniques with semi-structured interview methods using purposive sampling in selecting sources and then analyzed with SWOT analysis and described in the form of a matrix so as to produce several alternative SME's business strategies during the COVID-19 pandemic. The results showed that several sectors in Padangsidimpuan City felt the direct impact of the COVID-19 pandemic, such as the areas of public transportation and tourism which experienced a decline. Meanwhile, in the food sector it is still stable, but in services such as expeditions and delivery it has increased. The narrow space of movement between sellers and buyers that is happening now makes selling online the main solution. Businesses need to open up insight in thinking to start choosing e-marketing as a promotional path for goods and services to increase the number of sales transactions while still adhering to health protocols.
\end{abstract}

Keywords: Small and Medium Entreprise, Business Strategy, COVID-19

\section{INTRODUCTION}

Since the beginning of 2020, the world has been suffered from the COVID-19 pandemic included Indonesia too, which has been heavily affected in its economic sector, especially among business players in the Micro, Small and Medium Enterprises (MSMEs) sector, a report by the Central Bureau of Statistics for Gross Domestic Product (GDP) Indonesia saw a contraction in economic movements that weakened by $2.41 \%$ compared to 2019 , which was $4.97 \%$. This will affect the country's economic cycle.

Meanwhile according to Delima, (2016, p. 131) that one of the solutions that can be done to develop the regional economy is through Micro, Small and Medium Enterprises (MSMEs) or Usaha Mikro, Kecil, dan Menengah (UMKM). MSMEs have a great number of contribution as the backbone of the national economy. This sector has been able to absorb a large number of employees and has high flexibility to develop and compete with other companies that utilize large capital from the start (capital intensive). Therefore, it needs fast handling and adjustments that more eficients.

The economic and business sectors in Indonesia have experienced significant changes due to the Covid-19 outbreak. Many of the business players of small and medium enterprises (MSMEs) find the difficulty to manage businesses that are obstructed and even threatened to be closed. However, the business actors must be able to make new strategies in order to adapt toward the pandemic situation. The important thing that can be done by MSME actors is to remain focused on consumer needs, especially on increasing innovation and creativity of products or services in 
accordance with changes in consumer preferences and behavior, that Carson (1993, 189-204) and Gilmore et al (2001, p.6-11) felt marketing during the life cycle of the SME, will continue to develop because of the demands for new commodities and markets, as customer needs are satisfied, bearing in mind the owners' inherent characteristics and behaviors and the size and life cycle stage of the firm

Kiryanto stated that to overcome with the impact of the Covid 19 pandemic, researching and expanding the business are needed to increase the durability amid the crisis. Therefore, the business players are encouraged not to be complacent because the competition will be fierce.

Krisyanto added that MSMEs business actors must prepare the next generation for being pioneer and excellent in the future. This includes continuing to maintain good reciprocal relationships with vendors, suppliers and distributors. "MSMEs players must join their organization to help them expanding their business and networks. Collaborating with banks as strategic partners for gaining information, financing, and business development assistance is also an important factor".

Iqbal Harahap, one of the leading economic practitioners in Padangsidimpuan city, in a interview (16 July 2020), said that there are many types of Micro, Small and Medium Enterprises (MSMEs) around Padangsidimpuan city which are classified as well developed business, such as trading, food, transport, tourism, grocery stores and other service providers that are also directly affected by COVID-19 outbreak. According to him, the current limited space between sellers and buyers is making Digital Electronic systems as the main solution to overcome the distance created between buyers and sellers. Business players need to open their minds to start learning about online-based promotion

\section{LITERATURE REVIEW}

\section{Definition of Micro-Small-Medium Enterprises}

Small enterprises based on the size of the workforce according to the Indonesian Central Bureau of Statistics (BPS, 1988) consist of 5-19 workers including paid manual laborers, owner and family workers. Home industry is an industrial company that has a workforce of less than 5 people.

(RI: 2008) According to the Law No. 20 years 2008 about Micro, Small and Medium Enterprises (MSMEs), stated that "micro enterprises are productive businesses owned by individuals and / or individual business entities which have the following characteristics; has a maximum asset of 50 million and a sales turnover of 300 million per year. Meanwhile, productive economic businesses that are independent, which are run by individuals or business entities that are not the part of the company or branch of the company owned, controlled, or become a part of medium or large businesses directly or indirectly that meet the following criteria such as having assets of 50 million to 500 million and a turnover of 300 million to 2.5 billion are called small businesses.

Meanwhile, the definition of medium-sized enterprises is "productive economic enterprises independently, which are run by individuals or business entities that are 
not subsidiaries or branches of companies that are owned, controlled, or part of small businesses or large businesses directly or indirectly. Net assets or annual sales valued 500 million to 10 billion and a turnover of 2.5 billion to 50 billion (Tulus, 2019, p. 13). Apart from the definition above, MSMEs are also defined by various agencies, as follows:

a. Based on Law No. 9 of 1995 that regulates the size of small businesses according to the fixed assets (except land and buildings) at a maximum of $\mathrm{Rp}$ 200 million with a maximum annual turnover of Rp 1 billion. Meanwhile, based on Presidential Instruction No.10 of 1999 that regulates medium-sized enterprises, the benchmark for fixed assets (except land and buildings) for medium-sized businesses is IDR 200 million to IDR 10 billion.

b. Ministry of Cooperatives and small medium enterprise classify a business as small business if it has a turnover of less than IDR 1 billion per year. A business with a turnover of between Rp. 1 to Rp. 50 billion per year is a scope for medium-sized businesses

c. The Ministry of Industry and Trade decided that industries with an investment value of up to $\operatorname{Rp} 5$ billion are small and medium industries. Meanwhile, businesses with fixed assets of less than Rp. 200 million and annual turnover of less than Rp. 1 billion are classified as small businesses (according to Law No.9 of 1995).

d. Bank Indonesia classifies small businesses according to the Law No.9 of 1995, while for medium-sized enterprises, BI determines that the criteria for fixed assets are separated between manufacturing industry (Rp. 200 million to Rp. 5 billion) and non-manufacturing industry (Rp. 200 - 60 million). )

e. The Central Statistics Agency (BPS) classifies a business based on the quantity of labor. Businesses that consisting of 1-5 workers are called micro enterprises.

Businesses consisting of 6-19 workers are called small businesses. While medium-sized businesses consist of 20-99 workers and businesses consisting of at least 100 workers are called large businesses.

Stanley and Morse suggest a different classification, where an industry that has a workforce of 1 (one) - 9 (nine) people is classified as the home craft industry. Small industry has 10 (ten) - 49 (forty nine) people, medium industry has 50 (fifty) - 99 (ninety nine) people and large industry has a workforce of more than 100 (one hundred) people. Suryana, (2001, p. 84).

\section{Business Strategy}

Hofer in Tripomo (2005, p. 6) argues that a business strategy to recognize the opportunities and risks that will be faced by the business or $S B U$ (Strategic Business Unit) in the future also develops the human resource skills which can be used to meet the opportunities and risks. Thereby, the industry is capable to achieve the goals of the Strategic Business Unit (SBU) organization. Business strategy focuses on how to compete in a industry, certain product or market.

Meanwhile Cravend in Tripomo (2005, p. 37) states that business strategy is an organizational tool used to achieve its goals. Strategy unites all concept of 
management among the scope of business, mission, goals and objectives of an industry. Strategy development to maintain the quality of competitiveness, involve and replace strategies to pay attention to new changes that occur in the environment is an ongoing process.

Then it can be concluded that the business strategy is something that is very important in conducting business activities to gain profits, the ability to compete using the expected market segmentation and share.

\section{Business Strategy in Marketing}

Marketing is a comprehensive method of business activity for regulating, pricing, marketing and distributing products and services that meet the needs of existing and potential consumers. (ukmpustaka.unpad.ac.id).

According to Peggy Lambing and Charles L. Kuehi (Suryana, 2001, p. 98), marketing strategy is a guideline for entrepreneurial skills by researching analyzing previous market in developing the successful marketing strategies.

In the marketing, McCarthy that marketing management is classified into 4 (four) elements known as The Four Ps: Product, Price, Place, Promotion (Goi, 2009, p.15) These four elements are the result of reconstruction of the marketing mix concept that was originally introduced by Neil H. Bordern with 12 elements, namely product Planning, Pricing, Branding and Channels of Distribution, Personal Selling, Advertising, Promotions, Packaging, Display, Servicing, Physical Handling, and Fact Finding \& Analysis (Borden, 1984, p. 7 -12).

In marketing, Husein (2005, pp. 134-135) stated that marketing management is classified into 4 (four) parts which are often known as the marketing mix. There are several aspects to focus in order creating marketing mix, such as:

a. Product

The product and its development aspects are part of the internal bank scope regarding almost all companies activities. Much of the literature to date considers the role of SMEs primarily as suppliers of larger companies. When SMEs produce unique sustainability technologies or processes, they can use their innovation potential to move their customers in the supply chain towards more sustainable directions (Walker H, Preuss L. Fostering, 2008). Companies products are the results of Companies operational activities and are closely related to bank portfolio management.

b. Promotion

The promotion aspect has a policy that is usually divided into 4 (four) ways, as follows: Advertising, Public Relations, Sales Promotion, Personal Selling. Advertising can be implemented by placing advertisements in the mass media. Public Relation can be done by preparing brochures, conveying information or explanations about a product and positioning as sponsors. Sales Promotion can be done through payment or waiving certain funds. Personal Selling is usually implemented to main customers.

c. Place

The product delivery strategy is closely related to determining the location of the office. The method distributing the products and services has developed increasingly following technology change. The place aspect is still determined by the 
division of regions, where the area will be divided into primary (large quantity of customers), secondary (medium quantity of customers) and additional (small quantity of customers).

d. Price

The purpose of pricing a product is to maximize profits, increase market share, achieve leadership in product quality and maintain capacity. Pricing can be made through various forms of determination of interest, fees, discounts, and other administrative costs (Husein, 2005, h.134).

\section{Business Strategy in Production}

Production strategy is a method to determine the amount of productive capacity of a productive source by looking at productivity. Productivity is the amount of production from each unit of input, while the term of production is the term for product or output.

Producing a product or service requires human labor and natural resources, capital in all forms as well as the skill. Therefore, all elements that support value creation of a product or efforts to increase the value of products are referred to production factors. These production factors consist of:

a. Land or Natural Resources

b. Human labor or Human Resource

c. Capital

d. Management skills.

All efforts and capabilities that can support production are called productive. Related to the productive term, the four (4) factors of production above can be referred to as productive resources (Chigbo D, 2014).

However, even though all efforts and capacities that can accommodate the process are called productive, not all productive units have the same productive capacity. The method to see productive capacity of a productive resource is by seeing on productivity. Productivity means the amount of production that can be produced by each input unit, while the output is a product.

\section{Business Strategy in Management of Human Resources Development}

According to Husein (2005, p. 331), the strategy in the HRD (Human Resources Development) should describe the form and type of strategies of the operational management level based on the main strategies of Human Resource Management (HRM) and have been set at a higher management level.

Human Resource Management is a function to attract, develop and maintain reliable employees in order to conduct the required activities to meet organizational goals (Boone and Kurtz, 2002, p. 318).

\section{Financial Strategy}

According to Husein (2005, pp. 328-330), a strategy in the financial sector is part of a company to organize the acquisition of funds, utilize funds and 
simultaneously control these funds in order to maximize firm value. Funds can be obtained from various sources, included in internal and external sources. Furthermore, these funds will be invested both for long-term and short-term investments to earn a profit.

\section{Padangsidempuan City Economic Growth}

According to BPS in 2019, Padangsidumpuan economy grew by 5.51 percent compared to the previous year. Based on the production approach, the highest growth was the information and communication sector at 9.35 percent, followed by the health and social activities sector at 8.77 percent and service businesses at 8.65 percent.

Based on the expenditure approach, the LNPRT expenditure consumption achieved growth of 9.92 percent, which owned the consumption of gross fixed capital formation in second place at 6.35 percent and the component for household expenditure at 3.80 percent.

According to BPS in Padangsidimpuan, there are three business sectors that have quite dominant influence on the PDRB of Padangsidimpuan in 2019 such as wholesale and retail trade of car and motorcycle by 22.69 percent; construction 12.30 percent; and education services by 10.52 percent. Meanwhile, in terms of household expenditures (PKRT), the largest contribution was 62.37 percent, following the gross fixed capital formation (PMTB) component of 36.68 percent and the government consumption expenditure component of 19.57 percent.

Nominally, based on the current price of Padangsidimpuan PDRB in 2019 is Rp. 6,373,126 billion and GRDP at constant prices in 2010 reached Rp. 4,261,315 billion.

Based on the report from BPS, the growth rate in 2019 experienced a growth of 5.51. Therefore, it is necessary to have strategies to maintain the economic growth rate of the city in the covid-19 pandemic since the outbreak is anticipated in the city of Padangsidimpuan in 2020, based on the results of field analysis and the expert's statement about the pandemic COVID-19 impact of weakening the growth rate of MSMEs in the Padangsidimpuan city.

\section{SWOT Analysis}

SWOT analysis is a tool used for strategic planning and strategic management in organizations (companies). This tool can be used effectively to build a business strategy and even a strategy to compete (GÜREL, 2017).

According to Freddy Rangkuti, SWOT analysis is a systematic identification of factors to formulate strategies. Strategy is a very important tool to achieve goals (Porter: 1985). Meanwhile, according to Freddy Rangkuty (2005, p.183), strategy is a comprehensive master plan that explains how to achieve all the goals that previously set. Based on the popular dictionary (Mas'ud, 2000), strategy is tactic. Based on the definitions above, it can be concluded that strategy is a tactic or comprehensive master plan and an important tool that explains how to achieve all goals. This analysis is aimed to maximizes strengths and opportunities, but simultaneously minimizes weaknesses and threats. The decision-making process has to analyze strategic factors 
in current conditions. This is called a situation analysis, the most popular model that is called a SWOT analysis.

\section{METHODS}

\section{Research Models and Approaches}

The business strategy of Micro, Small and Medium Enterprises (MSMEs) is the main focus of this research, precisely in the city of Padangsidimpuan during the COVID-19 pandemic, the method used in this research is qualitative method.

The research method was used when analyzing the state of the natural object (natural setting), the role of the researcher is as a key instrument, the data collection system is carried out by triangulation (combined), the analysis $t$ is inductive and the research product emphasizes the meaning of generalization, where this is the definition of qualitative research methods. What must be owned by researchers in qualitative research that is holistic This qualitative research had holistic (global, unable to separate) characteristic to meet the facts contained in the field as mandatory requirement.

Conceptual aspects are very closely related to the analysis of qualitative research. The sampling method aimed to obtain various information from various sources and their construction to close the generalization approach, and the second purpose of sampling was to explore the deeper informations to be used as the main design and ideas that arise. Moleong, (2006, p. 117)

Thus, purposive sampling is a sampling technique that is usually used in qualitative research. Purposive sampling is a technique of collecting samples of data through special considerations.

\section{Data Analysis}

Descriptive analysis method is a method used in data analysis and describes the data using SWOT analysis. Furthermore, the data or information will be analyzed by the researcher where the data or information is in the form of exposure, qualitative research obtained during in-depth interviews related to the business strategy of Micro and Small Enterprises (MSMEs) in the city of Padangsidimpuan includes documentation related to the business strategy. The purpose of this research is to understand and recognize the business strategies executed by business operators in developing and managing their businesses during the COVID-19 pandemic.

\section{DISCUSSION}

The result showed that business operation will decline more while the COVID19 more. The regulations for staying at home and the respective quarantines trigger consumers to be increasingly isolated. The current crisis will pressure SME business players to survive. Some businesses may increase, but some are struggling for just one or two sales. This means that you as a business person need to pay attention to keep the business still going on. Below are seven strategies/policies for SME product marketing that can be applied during this pandemic. 


\section{MSMEs Business Strategies}

\section{Financial Strategy}

No one can confirm when the Covid-19 pandemic will end. Therefore, it is necessary to conduct a deeper investigation about the financial situation of the business, especially in the situation of business liquidity. Liquid assets or funding that can be used quickly to fulfill short-term obligations and classified as needs in crisis conditions is a definition of liquidity. Determinining the size of business liquidity and how long that liquidity capable to run will help the business survive during a pandemic.

Cash flow must be assured to be maintained properly. The most important element in a business is cash flow. Therefore, the business players must be able to manage capital or funds optimally. Another important thing to understand MSMEs is knowing customers behavioural changes. A changing of the place as the behavior instead of missing customer.

The decline in sales were caused by the decrease in consumers demand as indirect effect of COVID-19, raw materials were difficult to obtain, the profit decreased, and even got a loss. The impact of this pandemic made MSME actors experienced the difficulties in paying their credit installment obligations (failed to pay, their businesses did not operate for a long time, so their debt increased).

In financial issue, MSMEs finance needs to maintain the availability of funds for being able to pay their liabilities and early capital when they enter a state of recovery. In addition, there are other strategies that can be carried out by MSMEs by providing emergency subsidies to help the MSMEs' families and workers who have lost their income.

\section{Production Unit Strategy}

Production is an activity process where these activities can add value to a product or service. Amid this pandemic, MSME business players must anticipate and adapt to risks or changes that could occur inside economic flow. After business players predict the future existence of a business, they must be able to draft a new business plan containing strategic or marketing procedures, distribution procedures, capital schemes and expenditure systems. Thus, business players can promote their business to strengthten the business under complicated financial circumstances. Business layers are required to adapt on digital marketing procedures to save promotional costs and expand the range of distribution procedures.

There are several things as production main focus that can be done:

a. Avoid putting over stock items (limited to the required items)

b. Creating clear and focused target customers

c. Knowing the gap where business opportunities exist

d. The offered products have unique benefits, especially for self-care items

e. Knowing other competitors' business

f. Ensure our value proposition is superior to other competitors' proposition 


\section{Management of Human Resources Departement Strategy}

Human Resources (HR) is an important element in a business. Regardless of the purpose and form, MSMEs is formed with a number of visions for human needs and the implementation of its mission is managed by humans. Therefore, humans are a strategic aspect of all activities in a company. Furthermore, Human Resource Management (HRM) role is processing and handling Human Resources (HR) based on the vision of the organization to achieve optimal goals. Similar with many MSME players in Padangsidimpuan, the owner of a business markets various kinds of products that supported by several employees. The employees are recruited by MSME players from neighbors, friends or relatives who participate in helping business activity. Even, there are workers who come from areas outside Padangsidimpuan city.

During this pandemic, the quality or ability of these employees is a crucial internal factor to maintain stable sales for surviving. Improving the quality of business management is crucial because these players are forced to follow up with developing era and lead to the use of online media-based technology. People are starting to open their mind from the use of public transportation to choose online transportation applications because they think that this platform is more effective and easier for the community (Ferri, 2018, p. 8). Another example is the seller who initially just waited for buyers to come to the store or market, with the technology utilization, now they can come to consumers anywhere and anytime without worrying about the distance between the buyer and the seller due to the benefit online-based technology.

Therefore, business players must be able to open their way of thinking effectively to be more advanced and broader in taking advantage of today's developments according to the tastes or needs of consumers.

\section{Marketing Strategy}

The marketing mix strategy is depicted from the price point of view as well as its major function to attract and satisfy the costumers. Products that have good quality and reachable prices for consumers are the main attraction for this business. The price determination to costumer applied by MSMEs around Padangsidimpuan is aimed to have one item quality depending on the basic materials and complexity of the production process. The work and materials complexity affect the level of prices made by the organization.

The marketing strategy is known as 4Ps: product, place, price, and promotion. Marketing carried out by UMKM business players in Padangsidimpuan City could be explained as follow:

a. Product

Production using the existing equipment and facilities, production using a minimum amount of raw materials, production using a minimum amount of labor, production using minimal financial capital, opening more effective shoow-rooms / outlets, creating a side business is a strategy that can be done to develop the business. Recommendations of analysis result relates with the methods to elevate business recovery to create production activities again using financial or capital addition. 
b. Price

A business that grows has a general purpose to produce goods at an economical cost based on necessity and sell at a price that is in accordance with the purchasing power of its customers. During the pandemic, business players are required to be more innovative and creative to save increased production costs due to the increased price of raw materials on the market.

During this pandemic, Padangsidimpuan city price was still at the standard price, said Halomoan Harahap, Chairman of the Sagumpal Bonang Market Traders Association of Padangsidimpuan City (16 July 2020). However, along with the development of the COVID-19 outbreak, business players are forced to create sales innovations such as avoiding the risks to stock items that are not needed or attracted by the market in order to maintain financial cash flow and keep the stable prices.

During this pandemic, business players were also forced to offer more products at the lowest prices because the decreasing amount of demand or people power to purchase the good (not the self-care product). Another reason is focusing more on safety for unexpected and larger costs.

\section{c. Place or Distribution}

Starting a business is not simple specially to choose a business place where internal and external aspects must be considered. Entrepreneurs believe that the strategic location will attract more benefits. It is also a key to a successful business. However during this pandemic, selecting a location in the market or in a crowded place was not the main thing because social distancing regulations by government to maintain the space between sellers and buyers (Moan, 14 July 2020). Therefore, distribution through online media is a very effective solution to further expand the business.

\section{d. Promotion}

The definition of a product is the products or services marketed in a businesst. Promotion is a strategy implemented by business players to market these products. Thus, business players must be able to differentiate between products and offers based on the customer's perspective. Promotion is also used as an information tool, informing the customers or consumers about the product details to understand its use, existence, method of use, advantages, working method and the location where these items can be obtained quickly.

The strategy of product promotion is not promoting the strength of products but placing advertisements that can attract customer interest with elements of attention, interest, desire, and action, "said Iqbal in a direct interview (16 July 2020).

Business actors must pay more attention to the promotions and sales offered. Avoid all negative impressions that can damage the business brand. Another method is creating videos to consumers about how to guarantee and safe the implemented product. This can support the business players to minimize the entire risk caused by spreading the Covid-19 Virus. 
The current narrow space between sellers and buyers makes Digital Electronic system as the main solution to overcome the distance created between buyers and sellers. Business players need to broaden their mind in choosing online-based promotional channels, online-based sites and online-based service systems as transactional media in line with health regulations amid COVID-19 outbreak.

\section{e. Digital Electronic Utilization}

Marketing strategy must be determined by business players to continue selling well in the market. Business players try to understand the financial condition of the business to implement a relevant strategy regarding to financial situation. Businesses can utilize software and cloud-based financial accounting, for example, Journals. With the use of this software, everything will run in a fast and automatic system, businesspeople can easily align marketing with all changes in the future.

Businessman can also use this situation to improve skills and quality for further business development. One example is developing e-commerce as a part of proficiency in marketing through digital platform. Therefore, when the business grows normally, business operations can develop faster than before.

Business players can also carry out the automation process in their business. Basically, there are three important things in doing business, those are time, money and energy. Most business operators have money, but they do not have the time and energy because of its traditional methods. These factors can obstruct the growth of the business.

For this reason, business players must revise their business processes by changing manual recording to online accounting software, changing the employee salary payment process, which was originally manual to an automatic payroll system, or changing the traditional tax payment system to software system.

For instansce in the marketing line, business players can use technology as optimally as possible with digital marketing and social media. From the sales side, MSMEs can also take the advantage of online delivery services which are currently very popular among the public.

During this pandemic, many businesses have switched to using social platforms such as Twitter, WatsApp, Facebook and Instagram to promote their products and interact with consumers together with the implementation of \#dirumahsaja, spontaneous content consumption of social media content is increasing. Therefore, the business players take the advantage of this moment by being more active on social media.

Even if the business is forced to stop working temporarily, business players do not stop to post / promote their products. They use a business profile to show solidarity and stay in touch with customers. The businesses will have a tighter bond with consumers when the situation returns to normal.

\section{SWOT Analysis}

SWOT analysis is used as a basis for providing an overview of business conditions which includes internal resources (strengths and weaknesses) with external 
situations (opportunities and threats). The interview results with informants show that the strengths, weaknesses, opportunities, and threats in the development of MSMEs in Padangsdimpuan City are :

a. Strength

1. Food products in Padangsidimpuan are classified in stabil condition

2. Products in online platform are increased

3. Online transportation has increased significantly.

4. The knowledge and online based technology are increased.

5. Promotion cost is minimalized because the business players do not need to focus on promoting through physical media such as brochure, banner, but they just need to use social media or other online platforms

6. The beginner business players are getting the benefit through this situation because the business does not need to focus on physical place to trade their products, but they just enough utilize online platform wherever the transaction occurs.

7. Delivery service as the new work field are improving

b. Weakness

1. Less innovation and creativity among business players.

2. Marketing and Distributing are limited dan not conducted maximally

3. Minimal knowledge among business players about using digital platform for their business.

4. Limited knowledge about online marketing

5. Weakened demand from society because of over safety

6. Unstable economic growth due to export and import hinders

7. Weakened purchasing power due to limited salary during pandemy

8. Weakened turn over in otomotif and carpenter sector

9. Weakened turn over in tourism sector

c. Opportunity

1) Business opportunities with minimum capital for the business

2) Improving purchasing access in any situations and places.

3) Easeness daily goods consumption.

4) Shifted shopping trend to digital platform

5) Shifted economic ecosystem using digital based

6) More consumers use online fast-moving products.

7) Consumer behavior changing

8) Digitalisation or technology usage can be both used by consumers or sellers and will be a new continuity habit as the main media for transaction.

d. Threat

1) A small number of buyers because their insecurity of outbreak threat.

2) Business players who do not understand with digital platform will experience a stag selling state. 
3) Old fashioned and over stock products

4) The possibility of loss due to capital and products are not moving

5) The regulation of Pembatasan Sosial Berskala Besar (PSBB) or Big Scale of Social Distancing.

6) Tight competition among business players that use online platform

7) Uncertainty of the outbreak in the future

8) No formal promotion is predicted to no new consumer in the future

\section{CONCLUSION}

Product Strategy: to the results of an interview with Halomoan Harahap (chairman of the association of Sagumpal Bonang market, Padangsidimpun city) can be seen as follow:
a. Avoid over stock products that exceess the demand requirement
b. Creating a clear and focused consumer target
c. Knowing where the gap of business opportunity is
d. The products must have unique value proposition especially self care service
e. Knowing other business competitors
f. Assuring our offer is exceed other competitors' brand and offer

Financial strategy is necessary to carry out an in-depth examination of the financial condition of the business, especially on the business liquidity position. Liquidity is a number of funds or liquid assets that can be used quickly to pay shortterm obligations, including for emergencies purposes (emergency funds). Ensuring how much and how long liquidity of the business can run the business and let them survive during a pandemic.

This includes ensuring a healthy cash flow. Cash flow is the most important element in business, so business owners must be able to manage cash optimally. MSMEs must also understand consumer behavioural changes. The consumers do not disappear, but they change in the term of behaviour and place.

Management of Human Resources Development Strategy. During this pandemic, the quality or ability of employees is a very important internal factor to maintain stable sales in order to survive. Improving the quality of management of business is very important aspect because the business players are forced to keep up with developed era and lead to the use of online media-based technology. Business players must be able to open their minds in taking advantage of current developments more effectively based on the tastes or needs of consumers

Marketing Strategy. In terms of promotion, production with limited facilities / equipment, production with a limited number of raw materials, production with a limited number of workers, production with limited financial capital, opening more effective shoow-rooms / outlets. In terms of price, creating products that are cost efficient in accordance with needs and sell using the prices based on the purchasing power of consumers. During a pandemic, business actors must be able to be more innovative and creative to save the increased production costs due to the increasing 
price of raw materials on the market. In terms of place or distribution, distribution with online media is a very effective solution to further business expand of MSME players. In terms of promotion, the current narrow space between sellers and buyers imprompt Digital Electronic systems as the main solution to overcome the distance created between buyers and sellers. Business players need to open their minds to start choosing online-based promotion channels, online-based sites and online-based service systems as the medium or media for market transactions in line with regulations to comply with health protocols during the COVID-19 pandemic.

Digital Electronic Utilization. Businesses can use cloud-based software and financial accounting such as Journals. With an automatic and fast system, business players can adjust quickly their marketing to any changes in the future. Players can take the advantage of the circumstance to improve their expertise for future business development. For instance, creating digital platform or developing own e-commerce platform. Therefore, after the business runs normally, business operations can run faster than before. Maximize the use of online digital media-based for marketing media.

\section{REFERENCES}

Alfadri, ferri (2018), Pengaruh Adanya Transportasi Online, j-EBIS Vol. 3 No. 2

Borden, N.H (1984), The Concept of the Marketing Mix, Journal of Advertising Research (1984).

Carson, D. (1993). “A Philosophy for Marketing Education in Small Firms.” Journal of Marketing Management, 9.

Chibo, D. N, Management as a Factor of Production and as an Economic Resources, International Journal of Humanities and Social Science, Vol. 4, No. 6; April 2014.

Goi, C.L. (2009), A Review of Marketing Mix: 4 Ps or More? , International Journal of Marketing Studies (2009): 2-15.

GÜREL, E. \& TAT, M. Swot Analysis: A Theoretical Review, Journal of International Social Research, Vo. 10, Issue 51

Hunger, J. David dan Thomas L. Wheelen, (2003). Strategis Manajemen, Yogyakarta: UPP AMP YKPN.

Kotler, Philip dan A.B Susanto, (2001). Manajemen Pemasaran di Indonesia, Jakarta: Salemba Empat.

Lubis, Delima Sari, At-Tijaroh, (2016), Pemberdayaan UMKM Melalui Lembaga Keuangan Syariah Sebagai Upaya Pengentasan Kemiskinan Kota Padangsidimpuan, Volume 2, No. 2

Moloeng, J. Lexy, (2006). Metode Penelitian Kualitatif, Bandung : PT. Remaja Rosdakaryam

Rangkuti, Freddy, (2005). Analisis SWOT : Teknik membedah kasus bisnis, Jakarta: Gramedia Pustaka Utama

Republik Indonesia. (2008). Undang-Undang No. 20 Tahun 2008 tentang Usaha Mikro, Kecil, dan Menengah. 
Rita, (2014), Analisis Strategi Bisnis Usaha Mikro Kecil Menengah Toko Bunga “Cindy”, Jurnal Bisnis Indonesia Vol.5 No. 2

Subanar, Harimurti, (2001). Manajemen Usaha Kecil edisi Pertama, Yogyakarta : BPFE

Sugiyono, 2010. Metode Penelitian Bisnis : Pendekatan Kuantitatif, Kualitatif dan $R \& D$, Bandung : Alfabeta

Suryana, (2001), Kewirausahaan, Jakarta : Salemba Empat

Tulus, T. Recent evidence of the development of micro, small and medium enterprises in Indonesia, Journal of Global Entrepreneurship Research, 9:18

Walker H, Preuss L. Fostering, (2008), sustainability through sourcing from small businesses: public sector perspectives. Journal of Cleaner Production 